\title{
Evidence Based Practice and Advanced Competencies in a MHS-CLS Program
}

\author{
BARBARA RUSSELL, BARBARA KRAJ, LESTER PRETLOW \\ ANNE RANNE, ELIZABETH K. LEIBACH
}

\section{LEARNING OBJECIVES}

1. Discuss the criteria that were used in determining the need for the Master of Health Science in Clinical Laboratory Science degree.

2. Recognize the difference between foundational and advanced objectives.

3. Identify at least three advanced objectives that could be used in a hematology, chemistry or molecular methods course.

4. Discuss a hierarchical research model for undergraduate and graduate education in clinical laboratory science.

Clin Lab Sci 2011;24(4)Suppl;4-47

Barbara Russell, Ed.D. MLS(ASCP) ${ }^{C M}, S H(A S C P)^{C M}$, Georgia Health Sciences University, Augusta, GA

Barbara Kraj, MS, MLS(ASCP $)^{C M}$, Georgia Health Sciences University, Augusta, GA

Lester Pretlow, Ph.D., C(ASCP $)^{C M}$, Georgia Health Sciences University, Augusta, GA

Anne Ranne, MS, MT(ASCP), Georgia Health Sciences University, Augusta, GA

Elizabeth K. Leibach, Ed.D., M.S., MLS(ASCP) ${ }^{C M}$, $S B B(A S C P)^{C M}$, Georgia Health Sciences University, Augusta, $G A$

Address for Correspondence: Barbara Russell, Ed.D. $M L S(A S C P)^{C M}$, SH(ASCP) ${ }^{C M}$, Associate Professor and CLS Program Director, Department of Medical Laboratory, Imaging, and Radiological Sciences, Georgia Health Sciences University, EC-3340, 987 St. Sebastian Way, Augusta, Georgia 30912, (706) 721-7627, brussell@georgiahealth.edu

\section{ABSTRACT}

The goals, curriculum, implementation, and immediate impacts of an entry-level Master of Health Science in Clinical Laboratory Science (MHS-CLS) degree are described as compared to the baccalaureate program (BS-CLS) in the same institution. The MHS-CLS program was instituted in fall semester, 2008; the inaugural class graduated in spring semester 2010. To document the need for the MHS-CLS, program statistics, such as the number of students entering the current BS-CLS program with previous baccalaureate degrees, numbers of students graduating with biology and chemistry degrees in the United States, CLS workforce shortages and pending retirement statistics were used. The shortage of CLS practitioners able to perform and publish evidence-based practice research also supported program need. The MHS-CLS curriculum includes advanced courses, advanced competencies incorporated into existing BS-CLS courses, and a capstone research project in evidence based practice.

KEYWORDS: evidence based practice, health services research, health priorities, educational measurement, professional education, distance education, best practice analysis, clinical practice guidelines, problem-based learning, active learning, medical laboratory science

ABBREVIATIONS: MLS, medical laboratory scientist; CLS, clinical laboratory science; MHS-CLS, Master of Health Science in Clinical Laboratory Science; BS-CLS, Bachelor of Science in Clinical Laboratory Science; NAACLS, National Accrediting Agency for Clinical Laboratory Sciences; CDC, Centers for Disease Control and Prevention; IOM, Institute of Medicine; EBM, Evidence-Based Medicine; EBP, Evidence-Based Practice; IRB, Institutional Review Board 


\section{FOCUS: BUILDING RESEARCH THROUGH MLS CURRICULA}

\section{INTRODUCTION}

In fall 2008, after three years of planning, a major academic medical center offering a baccalaureate degree in clinical laboratory science since 1959 instituted a novel entry-level, with added advanced practice curriculum, Master of Health Science in Clinical Laboratory Science (MHS-CLS) degree. The impetus for starting an entry-level MHS-CLS degree was threepronged. First, the program statistics had shown that from 2001-2007, 56\% of the students who enrolled in the Bachelor of Science in Clinical Laboratory Science (BS-CLS) program held a prior baccalaureate degree in a related life-science, e.g., chemistry, biology. Based on these data and on casual interviews with the students, the faculty believed that students would prefer to obtain a master's degree instead of a second bachelor's degree and this would be a recruitment incentive. The second reason was the reported age of medical laboratory scientist (MLS/CLS) professionals currently practicing. Georgia Hospital Association reported in 2006, that approximately $40 \%$ of practitioners were over the age of $50 .{ }^{1}$ For this reason, the faculty incorporated into the MHS-CLS curriculum advanced competencies that would give graduating students advanced practice skills to help fill the developing void that would be experienced with the loss of so many practitioners. Third, was the need for MLS/CLS practitioners who could assess the effectiveness of laboratory services delivery through the design, implementation, and evaluation of quality improvement studies, i.e., practitioners who could perform evidence-based research in the field of clinical laboratory science. The purpose of this paper is to describe the goals, design, and immediate outcomes of the entry-level MHS-CLS program.

\section{Program and National Statistics}

As stated above, $56 \%$ of students enrolled in the BSCLS program from 2001-2007 already had a baccalaureate degree in a foundational life science, such as biology or chemistry. Additionally, $5 \%$ had a postbaccalaureate degree. The National Center for Education Statistics reported that in the 2008-2009 academic year there were 55,856 students graduating with a baccalaureate biology degree in the United States. ${ }^{2}$ There were 11,851 students graduating with a chemistry degree, ${ }^{3}$ and 2,480 with a microbiology degree. $^{2}$ The Bureau of Labor Statistics reported that for biological scientists, employment is expected to grow faster than average. However, a Ph.D. is required for most graduates to work in academia; biological science graduates with baccalaureate degrees have more opportunities in non-academic positions and in healthcare. ${ }^{4}$ For chemists, the Bureau of Labor Statistics reported that growth is expected to be slower than average. Ph.D.-prepared chemistry graduates have better employment opportunities than those with baccalaureate degrees. ${ }^{5}$

There are shortages of medical laboratory science practitioners across the Southeast and the nation. For instance, Georgia Hospital Association (GHA) reported that in 2006 the vacancy rate for MLS practitioners was $13.3 \%{ }^{1}$ and Georgia Department of Labor reported that there were 5,440 positions held by clinical laboratory scientists in 2008 with 210 openings per year. ${ }^{6}$ The U.S. Bureau of Labor Statistics stated that the job outlook for CLS is expected to be excellent with rapid job growth in hospitals and even better growth in settings other than hospitals. ${ }^{7}$

The faculty understood that the shortage of MLS practitioners across the Southeast and the nation was an issue that all educators must address. They also realized that there was a potentially large post-graduate applicant pool seeking healthcare careers. The faculty believed that master's degrees would be more appealing to these students than obtaining additional baccalaureate degrees. Therefore, the CLS program sought to expand the applicant pool by offering an entry-level MHS-CLS degree to increase the number of students graduating with a degree in clinical laboratory science thereby increasing the number of practitioners.

\section{Advanced Competencies}

The second impetus for creating the entry-level MHSCLS degree was the need to have graduates with advanced practice skills. GHA reported that in 2006, $70.4 \%$ of practicing clinical laboratory scientists within the state were over the age of 40 and $39.8 \%$ were over the age of $50 .{ }^{1}$ Addressing national data, Garcia et al. reported from survey findings that a staffing challenge for laboratory managers would be replacing the baby boomers when they retire. In this survey, laboratories reported that the percentage of employees planning to retire in the next five years, as defined by their own internal metrics, ranges from $14.2 \%$ in blood bank to $17.9 \%$ in immunology. ${ }^{8}$

There will be a need to replace these retiring 


\section{FOCUS: BUILDING RESEARCH THROUGH MLS CURRICULA}

management staff with practitioners who have advanced skills. Beck and Doig reported that CLS educators, practitioners, and managers concluded that future practitioners would need more skills in management and administration. During the first year of practice, practitioners would need skills in laboratory operations, such as routine testing, analytical principles, problem solving, and quality control. However, after 3-5 years, CLS practitioners would need to have more advanced skills, such as performing turn-around time studies, writing laboratory procedures and manuals, performing needs assessments for new test methodologies, preparing staff schedules, monitoring tests costs, participating in hospital-wide committees, and consultation with other healthcare providers on the significance of laboratory test results and their predictive values. These authors concluded that practitioners will have to rely on their CLS education to prepare them for these additional skills. ${ }^{9}$

An American Society for Clinical Laboratory Science 2009 position paper identified advanced skills that practitioners with a baccalaureate degree with additional education or a master's degree would need. Some of these advanced skills were patient education, technical supervision, research protocols, quality management oversight, method evaluation, business management operations, and advanced techniques in molecular diagnostics. ${ }^{10}$ Given impending retirements and requirements for CLS higher-order practice within 3-5 years of graduation, advanced competencies taught in the CLS curriculum would help prepare new graduates for advanced practice and rapid promotion upon hire.

\section{Evidence Based Practice}

In 2008, the Centers for Disease Control and Prevention reported the value and pivotal role of laboratory medicine in healthcare delivery. The report described how laboratory medicine supports the six aims of quality identified by the Institute of Medicine (IOM) in 2000: (1) safety, (2) effectiveness, (3) patientcentered care, (4) timeliness, (5) efficiency, and (6) equity. ${ }^{11}$ The CDC reported that heath care organizations are using these broad aims to develop procedures and practices to improve patient outcomes. Laboratory medicine's efforts toward these aims included the establishment of performance indicators related to the effectiveness of laboratory services delivery in the assurance of quality patient care. The identification, implementation, and assessment of these performance measures constitute evidence-based medicine (EBM). The use of rigorously developed EBM methods can create the strength of evidence necessary for the development of these best practices related to IOM aims. ${ }^{11}$

Evidence Based Medicine as defined by Sackett is "the conscientious, explicit, and judicious use of current best evidence in making decisions about the care of individual patients." ${ }^{2}$ Leibach modified this statement to "The conscientious, explicit, and judicious use of the best evidence from CLS in making decisions about the care of individual patients." ${ }^{13}$ Based on this modification, Leibach and Russell defined a typology of evidence based practice (EBP) for the baccalaureate and master's-prepared clinical laboratory scientists and for the terminal degree in CLS, the Doctorate in Clinical Laboratory Science. ${ }^{13}$ Table 1 displays a hierarchical research model for undergraduate and graduate education that summarizes, for each educational level, hierarchical learning constructs utilized in the research process: (1) review of the literature, (2) research design, (3) analytical techniques, and (4) research ethics.

In order to have CLS/MLS practitioners ready to perform EBP research, these constructs must be taught, learned, and applied in a logical sequence. Sequential delivery of EBP tenets from descriptive statistics in a baccalaureate-level curriculum through the EBP research project in the MHS-CLS program prepares graduates with advanced skills required for the current demands of clinical practice. Therefore, the incorporation of EBP tenets into a master's level curriculum is achievable and represents a foundational component of advanced practice.

\section{MHS-CLS Program at GHSU}

Upon completion of the three-pronged needs assessment, curriculum planning began and the first class was admitted fall 2008. Students entering the MHS-CLS program must have a baccalaureate degree in a foundational life science, a Graduate Record Examination (GRE) score of 1000 or above, and must meet the minimum grade point average requirement of 2.75 ( 4.0 scale). The program consists of 28 courses totaling 74 semester credit hours.

Designed as an accelerated (5 semester) course of study that will prepare individuals for positions in clinical 


\section{FOCUS: BUILDING RESEARCH THROUGH MLS CURRICULA}

healthcare, industry and research, master's-level professional competencies are introduced in the MHS-

Table 1. Hierarchical Research Models for Undergraduate and Graduate Education

\begin{tabular}{|c|c|c|c|}
\hline $\begin{array}{l}\text { Content } \\
\text { Area }\end{array}$ & Baccalaureate & Master's & Doctorate \\
\hline $\begin{array}{l}\text { Literature } \\
\text { Reviews }\end{array}$ & $\begin{array}{l}\text { Critical } \\
\text { appraisal }\end{array}$ & $\begin{array}{l}\text { Critical } \\
\text { appraisals } \\
\text { Systematic } \\
\text { reviews }\end{array}$ & $\begin{array}{l}\text { Critical appraisal } \\
\text { Systematic } \\
\text { reviews } \\
\text { Utilization of } \\
\text { evidence from } \\
\text { reviews }\end{array}$ \\
\hline $\begin{array}{l}\text { Research } \\
\text { Designs }\end{array}$ & $\begin{array}{l}\text { Quality control } \\
\text { studies } \\
\text { Method } \\
\text { comparisons }\end{array}$ & $\begin{array}{l}\text { Cross-sectional } \\
\text { Cohort }\end{array}$ & $\begin{array}{l}\text { Cross-sectional } \\
\text { Cohort } \\
\text { Quasi- } \\
\text { experimental } \\
\text { Experimental } \\
\text { Randomized } \\
\text { controlled trials }\end{array}$ \\
\hline $\begin{array}{l}\text { Analytic } \\
\text { Techniques }\end{array}$ & $\begin{array}{l}\text { Case studies } \\
\text { Descriptive } \\
\text { statistics }\end{array}$ & $\begin{array}{l}\text { Descriptive } \\
\text { statistics } \\
\text { Test parameter } \\
\text { analyses } \\
\text { Inferential statistics }\end{array}$ & $\begin{array}{l}\text { Inferential } \\
\text { statistics } \\
\text { Qualitative } \\
\text { analyses } \\
\text { Meta-analyses }\end{array}$ \\
\hline $\begin{array}{l}\text { Research } \\
\text { Ethics }\end{array}$ & $\begin{array}{l}\text { No-human } \\
\text { subjects }\end{array}$ & $\begin{array}{l}\text { Human research } \\
\text { exempt \& } \\
\text { expedited } \\
\text { review }\end{array}$ & $\begin{array}{l}\text { Human } \\
\text { research, } \\
\text { expedited } \\
\text { and full review }\end{array}$ \\
\hline
\end{tabular}

CLS curriculum in two ways: (a) advanced practice courses, augmenting the baccalaureate curriculum and (b) advanced professional competencies that are added to course requirements for MHS-CLS students to expand the entry-level professional certification competencies.

Both undergraduate and graduate programs have NAACLS accredited distance options. The CLS program maintains a mobile laboratory program site with on-site faculty serving a large metropolitan area within the state and students at both academic levels. In addition, individual students in both BS-CLS and MHS-CLS programs are located at clinical affiliates across the country. Distance curricula at both academic levels are delivered identically to the referent campus programs. Campus-based faculty, as well as faculty at the mobile laboratory site, digitally record lecture material via a video capture system, Tegrity, and upload for online access through the course management system, Vista. Campus and mobile laboratory faculty also collaborate with distance clinical instructors to guide students in their capstone project research and project production.

\section{Advanced Practice Courses}

The MHS-CLS program is significantly more advanced in academic content than the pre-existing BS-CLS program. Incorporated into the MHS-CLS curriculum are advanced practice courses in molecular methods, evidence based practice, clinical services delivery, biostatistics and epidemiology, and clinical patient management. These courses have been included in the curriculum to prepare graduates with advanced professional skills that are needed by employers in health care and the supporting manufacturing industry. These MHS-CLS courses additional to the BS-CLS curriculum are shown in Table 2.

\section{Advanced Professional Competencies}

In addition to master's-level courses, advanced professional competencies have been added to each of the entry-level, NAACLS-accredited courses. In each of these courses, MHS-CLS students have to complete all entry-level competencies required of the bachelor-level student as well as advanced competencies. Each entrylevel course has added advanced competencies that account for $10-30 \%$ of course content. These advanced competencies are incorporated into the courses as advanced cognitive and advanced psychomotor objectives and are coupled with formative and summative evaluations to ensure their accomplishment.

Table 2. MHS-CLS Advanced Practice Courses

\begin{tabular}{lc}
\hline Course Name & $\begin{array}{c}\text { Semester } \\
\text { Credit Hours }\end{array}$ \\
\hline Introduction to Epidemiology and Biostatistics & 3 \\
Evidence Based Practice & 2 \\
Research Process & 3 \\
Project Development & 2 \\
Clinical Molecular Methods Internship & 4 \\
Clinical Patient Management & 3 \\
Research Project & 3 \\
\hline
\end{tabular}

In addition, mechanisms are available for acceleration through entry-level technical competencies for MHSCLS students with previous MLS experience and formal education, e.g., baccalaureate-prepared medical laboratory technologists. Successful completion of 


\section{FOCUS: BUILDING RESEARCH THROUGH MLS CURRICULA}

advanced competencies affirms masters-level students' additional knowledge and practice skills in clinical chemistry, clinical hematology, clinical immunohematology, clinical immunology, clinical microbiology, clinical molecular methods, education, and clinical services delivery above and beyond that of the entry-level student. Examples of advanced competencies are displayed in Tables 3-5.

Table 3. Examples of Advanced Objectives in Hematology Laboratory Course

The student will:

1. perform three bone marrow differentials on normal bone marrow specimens with $70 \%$ accuracy;

2. perform three bone marrow differentials on abnormal bone marrow specimens with $70 \%$ accuracy;

3. given a particular patient history and hematological studies, evaluate a bone marrow specimen and select the appropriate specimens for ancillary studies;

4. interpret iron stains on bone marrows;

5. correlate marrow iron stores with various diseases;

6. construct a bone marrow report form.

\section{Capstone Research Project}

In addition to advanced courses and competencies, MHS-CLS students must complete capstone research projects. Research projects are structured as the culmination of program requirements and are comparable in academic rigor to the masters-level thesis. Students use information obtained from specific program courses, such as Evidence Based Practice, and the literature to craft a well-defined research question that the student, through guided research, can answer. They must complete an extensive literature review, develop research questions, and propose methods to answer these questions. Once the project has been approved by their major research advisor and the department chair, students must undergo training in human subjects research (Collaborative Institutional Training Initiative, CITI, online education), completing and submitting all paperwork required of the campus Institutional Review Board (IRB) as well as the IRB of the institution at which research data are collected. Upon IRB approval, students collect and analyze data. Students then present and defend the results of their investigations in a formal venue and complete research papers of publishable quality.

The MHS-CLS advanced practice courses include a five-course research sequence begun the first semester of enrollment: Statistics and Epidemiology, Evidence Based Practice, Research Process, Project Development, and Research Project. During the Evidence Based Practice course, faculty help students identify research topics of interest and, in collaboration with clinical practitioners at internship sites, formulate research projects that would be relevant to the institution where the research will be conducted. In addition, clinical practitioners at clinical affiliates have opportunities to oversee and contribute to research projects from beginning to the end, with the goal of using these findings in practice. During the remaining three semesters of the program, students hone research questions, review relevant literature, prepare IRB submissions, collect and analyze data, write reports, and present findings.

Table 4. Examples of Advanced Objectives in Chemistry /Immunology Internship Course

The student will

1. review proficiency testing records for the chemistry or immunology laboratory;

2. analyze an error in proficiency testing or test result reporting including problem- action-root-cause analysis;

3. submit a written report of their findings.

Table 5. Examples of Advanced Objectives in Diagnostic Molecular Methods Laboratory Course

The student will

1. design and submit for approval an assay to amplify a gene of choice (or its fragment);

2. perform the designed assay (see advanced cognitive objective 1 above);

3. maintain proper records of the outcome/s of the performed assay;

4. write a critical review of the performed assay based on its outcomes.

\section{DISCUSSION}

The goals of the MHS-CLS program developed by the faculty are to graduate professionals who enter into advanced leadership roles in CLS, conduct EBP research within CLS, collaborate effectively with other members of the healthcare team to improve patient outcomes and contribute to the CLS profession. By surveying graduates the faculty will determine if these goals have been realized. It is estimated that it will take a 


\section{FOCUS: BUILDING RESEARCH THROUGH MLS CURRICULA}

minimum of five years' data to adequately determine the significance of outcomes relative to goals.

The goals listed above are tangible measurements of program success. However, there are subjective indicators of success related to the completion of a master's degree, such as increased self-esteem and confidence and the ability to read and interpret scientific literature, that are considered desirable outcomes for the profession. Li et al., in two articles, outlined how CLS careers were enhanced by advanced degrees. They reported in the first article that more master's students wrote professional publications and when asked, master's students were more likely to list active participation in professional organizations than baccalaureate students. ${ }^{14}$ In the second article, Li et al. found that when asked, both baccalaureate-prepared and masters level practitioners reported increased selfesteem and confidence as a perceived benefit of an advanced degree. In addition, master's students reported personal satisfaction as motivation for, and benefit of, obtaining this degree. ${ }^{15}$ Fenn and Knight surveyed graduates from the University of Utah master of science program in clinical laboratory science between the years of 1969 and 1994. Graduates reported that the skills and knowledge obtained in graduate education used in their current positions were communication, writing, research, and critical independent thinking. ${ }^{16}$

Since the inception of the program, 33 students have chosen to enroll in the MHS-CLS even though this program takes an additional semester to complete and is more intense than the BS-CLS. Clinical faculty have noted that they have been impressed with the level of commitment of these students provided comments such as:

- "The Master's students stayed on top of the course assignments and always went above and beyond expectations when completing the assignments."

- "We were very impressed with the enthusiasm, dedication and commitment shown by these students and we appreciated and enjoyed having them."

Twenty-three students have completed research projects or are in the last stages of project completion since program inception. These projects are providing scholarship opportunities for faculty and students, as they work together on the publication of this research. There are many metrics that must be measured over the next few years to determine the success of this advanced program. Some of these will be enrollment numbers, performance on the certification examination, project quality, post-graduate positions, and careeradvancement. Qualitative measures such as career satisfaction, collaboration with other members of the healthcare team, increase in self-esteem and confidence will be measured through surveys to determine if the graduates' goals of obtaining an advanced degree in CLS were realized.

\section{CONCLUSION}

A novel entry-level MHS-CLS program was developed to address three strategic objectives of our university. The first stemmed from the fact that more than half of the students who enrolled in the BS-CLS program already had obtained a baccalaureate degree in a related life science. As the U.S. Department of Statistics demonstrated, there are thousands of students graduating each year with a degree in biology, chemistry, and microbiology. The second reason was the need to have entry-level graduates with advanced competencies who could help fill the void that will be experienced with the retirements that will be realized in the next few years. Last but not least, is the need to have practitioners who are able to perform and publish evidence based practice research in the field of clinical laboratory science.

The program curriculum includes advanced courses in molecular methods, evidence based practice, clinical services delivery, biostatistics and epidemiology, and clinical patient management; incorporation of advanced competencies into entry-level courses; and a capstone evidence based research project. Immediate feedback regarding program quality, vis-à-vis MHS-CLS students' clinical skills and knowledge, has been very favorable. In addition, additional practitioners are entering the workforce as a consequence of tapping the post-baccalaureate application pool. Formal mechanisms to measure both objective and subjective program outcomes over time are in place and the survey of graduates to determine their perceptions of the value of the program in their careers is on-going.

\section{REFERENCES}

1. Georgia Hospital Association. Georgia Hospital Association 2006 Workforce Report: Changing Demographics, Building Generations. Available from http://www.gha.org/Keyissues/ GHAWorkforce.pdf. Accessed 2011, March 15. 
2. U.S. Department of Education, Institute of Education Sciences, National Center for Education Statistics. Table 300: Degrees in biology, microbiology, and zoology conferred by degree-granting institutions, by level of degree: 1970-71 through 2007-08. Available from http://nces.ed.gov/programs/ digest/ d10/tables/dt10_311.asp. Accessed 2011, May 18. Last updated July 2010.

3. U.S. Department of Education, Institute of Education Sciences, National Center for Education Statistics. Table 314: Degrees in chemistry, geology and earth science, and physics conferred by degree-granting institutions, by level of degree: 1970-71 through 2007-08. Available from http://nces.ed.gov/ programs/digest/d10/tables/dt10_325.asp. Accessed 2011, March 30. Last updated August 2010.

4. United States Department of Labor, Bureau of Labor Statistics. Occupational Outlook Handbook, 2010-2011 Edition: Biological Scientists. Available from http://www.bls.gov/oco/ ocos047.htm\#emply. Accessed 2011, March 30. Last updated December 17, 2009.

5. United States Department of Labor, Bureau of Labor Statistics. Occupational Outlook Handbook, 2010-2011 Edition: Chemists and Material Scientists. Available from http://www.bls.gov/oco/ocos049.htm\#outlook. Accessed 2011, March 30. Last updated December 17, 2009.

6. Georgia Department of Labor. Occupational Outlook. Available from http://explorer.dol.state.ga.us/mis/occupation. htm. Accessed 2011, May 18. Last updated October 5, 2010.

7 United States Department of Labor, Bureau of Labor Statistics. Occupational Outlook Handbook, 2010-2011 Edition: Clinical Laboratory Technologists and Technicians. Available from http://www.bls.gov/oco/ocos096.htm. Accessed
2011, March 30. Last updated September 29, 2010.

8. Garcia E, Bennett A, DeFranco M, et al. American Society for Clinical Pathology's 2011 vacancy survey of U.S. clinical laboratories. Lab Medicine 2011;42:199-206.

9. Beck S, Doig K. CLS competencies expected at entry-level and beyond. Clin Lab Sci 2002;15(4):220-8.

10. American Society for Clinical Laboratory Science. 2009 Position paper: Practice levels and educational needs for clinical laboratory personnel. Available from http://www.ascls.org/ ?page= Pos_Pap_2. Accessed 2011, March 30.

11. Centers for Disease Control. Laboratory medicine: A national status report.(2008). Available from https://www.future labmedicine.org/pdfs/2007\%20status\%20report\%20laboratory _medicine_-_a_national_status_report_from_the_lewin_ group.pdf. Accessed 2011, March 30.

12. Sackett D, Rosenberg WM, Gray J, et al. Evidence-based medicine: What it is and what it isn't. Br Med J 1996;312:712.

13. Leibach EL, Russell BL. A typology of evidence based practice research heuristics for clinical laboratory science curricula. Clin Lab Sci 2010;23(1):47-50.

14. Li RC, Bigler WN, Blackwood LL, et al. CLS advanced degree and career enhancement: Part 1 - comparison of career data. Clin Lab Sci 1998;11(1):21-7.

15. Li RC, Bigler WN, Blackwood LL, et al. CLS advanced degree and career enhancement: Part 2 - a comparison of perceptions. Clin Lab Sci 1998;11(1):28-34.

16. Fenn JP, Knight JA. The value of graduate education in clinical laboratory science. Lab Med 1995;26:537-41.

\begin{tabular}{|c|}
\hline $\begin{array}{c}\text { Member Renewal } \\
\text { Thank You! }\end{array}$ \\
\hline $\begin{array}{l}\text { ASCLS wants to THANK YOU for } \\
\text { renewing your membership for the } 2011 \text { - } \\
12 \text { year! } \\
\text { aSCLS is offering } 6 \text { online quizzes at } \\
\text { no charge to help with your CE needs } \\
\text { For details* about the offer and } \\
\text { order form, go to www.ascls.org/ } \\
\text { ?Edu_MTY } \\
\text { We know you have choices as to } \\
\text { which organization you belong and we } \\
\text { are thrilled you chose ASCLS! }\end{array}$ \\
\hline $\begin{array}{l}\text { * For PF1, PF2 \& FYP members who } \\
\text { renewed by } 9 / 30 / 11 \\
\text { *Must complete quizzes by } 7 / 31 / 12\end{array}$ \\
\hline
\end{tabular}

